\title{
Field Trials of Febantel against Gill Fluke Disease Caused by the Monogenean Heterobothrium okamotoi in Cultured Tiger Puffer Takifugu rubripes
}

\author{
Takeshi Kimura $^{1 *}$, Yoshinori Nomura ${ }^{2}$, Hidemasa Kawakami ${ }^{3}$, Tomokazu Itano ${ }^{3}$ \\ Masahiko Iwasaki ${ }^{4}$, Jun Morita ${ }^{5}$ and Jungo Enomoto ${ }^{6}$ \\ ${ }^{1}$ Kumamoto Prefectural Fisheries Development Division, Kumamoto 862-8570, Japan \\ ${ }^{2}$ Kumamoto Prefectural Fisheries Research Center, Kumamoto 869-3603, Japan \\ ${ }^{3}$ Ehime Prefectural Fish Disease Control Center, Ehime 798-0087, Japan \\ ${ }^{4}$ Amakusa Fisheries Research Center, Kumamoto 866-0325, Japan \\ ${ }^{5}$ Animal Health Dept. Research and Development, Agricultural and Veterinary Division, \\ Meiji Seika Kaisha, Ltd., Tokyo 104-8002, Japan \\ ${ }^{6}$ Animal Health Dept. Agricultural and Veterinary Research, Meiji Seika Kaisha, Ltd., \\ Kanagawa 222-8567, Japan
}

(Received June 30, 2008)

\begin{abstract}
We conducted six field trials on the efficacy of febantel against the monogenean Heterobothrium okamotoi infecting cultured tiger puffer Takifugu rubripes at four sites in Kumamoto and Ehime, Japan. From 2,500 to 4,500 one-year-old tiger puffers per experiment group were used in these trials, in which tiger puffer were orally administrated febantel at 12.5 or $25 \mathrm{mg} / \mathrm{kg}$ fish/day for 5 days. The maximum rate of worm eradication was $80.9 \%$. However, a large difference was observed in the eradication rate between the experiment groups. We observed no adverse effect of febantel such as decreased appetite or increased mortality on the experimental fish.
\end{abstract}

Key words: febantel, Heterobothrium okamotoi, Takifugu rubripes, tiger puffer, clinical trial

The monogenean Heterobothrium okamotoi is a gill fluke affecting tiger puffer Takifugu rubripes. This infection is a serious disease affecting cultured tiger puffer (Okamoto, 1963; Ogawa and Inouye,1997a; Ogawa, 2002). Febantel is a pro-drug of fenbendazole and widely used in veterinary medicine. We investigated whether febantel is effective against this gill fluke disease in a previous study (Kimura et al., 2006). Febantel is metabolized to fenbendazole in tiger puffer in the same manner as in other animals given the drug orally, and the effective dose against $H$. okamoto in fish is 12.5 or $25 \mathrm{mg} / \mathrm{kg}$ body weight with daily administration for 5 days (Kimura et al., 2006).

In the field, $H$. okamotoi infection levels are variable (Ogawa and Inouye, 1997a). In addition, cultured tiger puffers are affected by changes in water temperature, dissolved oxygen (DO), etc. and can be infected by many types of parasites, including Neobenedenia girellae, Gyrodactylus rubripedis and Trichodina fugu (Ogawa and Inouye, 1997b). Therefore, it is very important to confirm whether comparable results can be obtained in naturally infected tiger puffers. We investi-

\footnotetext{
* Corresponding author

E-mail: kimura-t-dz@pref.kumamoto.lg.jp
}

gated efficacy against $H$. okamotoi in the field, where tiger puffer are cultured in the thousands in net cages.

\section{Materials and methods}

Experimental fish and location

In this study, we used one year old tiger puffer infected with $H$. okamotoi in the culture field. In total seven trials were carried out from September to December of 2003 in four fish farms located in Goshoura, Amakusa City, Kumamoto Prefecture and Mikame, Uwajima City, Ehime Prefecture. Five trials, Test A-1 and $\mathrm{A}-2$, Test $\mathrm{B}$, and Test $\mathrm{C}-1$ and $\mathrm{C}-2$, were carried out in the three fish farms in Kumamoto. One trial, Test $\mathrm{D}$, was carried out in a fish farm in Ehime. These fishes were cultured using net cages, 7-10 m long $\times 7-10 \mathrm{~m}$ wide $\times 4.5-10 \mathrm{~m}$ deep for each group. The experimental period of 13 days consisted of 5 days before febantel administration, 5 consecutive days of drug administration and 3 post-administration days. Body weights of 50 fishes from each experimental group were measured at the start of the experiment, and the total weight of the drug was estimated for each group. Numbers of $H$. okamotoi parasites in 20 fish from each experiment group were counted at the start and completion of the 
Table 1. Summary of field trials of febantel against Heterobothrium okamotoi of cultured tiger puffer

\begin{tabular}{|c|c|c|c|c|c|c|}
\hline Location & Test No. & $\begin{array}{l}\text { Experimental } \\
\text { group }\end{array}$ & $\begin{array}{c}\text { Average body } \\
\text { weight }(\mathrm{g})\end{array}$ & Number of fish & Experimental period (days) & $\begin{array}{l}\text { Feeding } \\
\text { rate* }\end{array}$ \\
\hline & & control & 68.8 & 3,683 & & \\
\hline \multirow[t]{15}{*}{ Kumamoto } & $A-1$ & $12.5 \mathrm{mg}$ & 64.2 & 3,625 & Sept. 12-23 (13) & 5.0 \\
\hline & & $25 \mathrm{mg}$ & 69.7 & 3,588 & & \\
\hline & & control & 110.1 & 2,700 & & \\
\hline & $A-2$ & $12.5 \mathrm{mg}$ & 111.6 & 2,700 & Oct. 23-Nov. 5 (13) & 3.0 \\
\hline & & $25 \mathrm{mg}$ & 107.6 & 2,700 & & \\
\hline & & control & 53.6 & 4,510 & & \\
\hline & B & $12.5 \mathrm{mg}$ & 73.5 & 3,130 & Oct. 31-Nov. 12 (13) & 4.0 \\
\hline & & $25 \mathrm{mg}$ & 80.6 & 3,450 & & \\
\hline & & control & 79.3 & 2,800 & & \\
\hline & $\mathrm{C}-1$ & $12.5 \mathrm{mg}$ & 83.2 & 3,000 & Dec. $18-30$ (13) & 3.0 \\
\hline & & $25 \mathrm{mg}$ & 83.8 & 3,000 & & \\
\hline & & control & 105.6 & 2,864 & & \\
\hline & C-2 & $12.5 \mathrm{mg}$ & 112.0 & 2,863 & Dec. $18-30(13)$ & 1.5 \\
\hline & & $25 \mathrm{mg}$ & 108.9 & 2,478 & & \\
\hline & & control & 207.5 & 3,200 & & \\
\hline \multirow[t]{2}{*}{ Ehime } & $\mathrm{D}$ & $12.5 \mathrm{mg}$ & 214.4 & 3,700 & Nov. 19-Dec. 3 (13) & 2.2 \\
\hline & & $25 \mathrm{mg}$ & 199.6 & 3,700 & & \\
\hline
\end{tabular}

* (Wet weight of feed/fish body weight $) \times 100(\%)$.

experiment.

The dose for the two febantel-administration groups were $12.5 \mathrm{mg} / \mathrm{kg}$ (low dose) and $25 \mathrm{mg} / \mathrm{kg}$ (high dose) body weight per day for 5 days. Control fish without administration of the drug were set for each trial. Body weights, fish numbers, examination periods and feeding rates are summarized in Table 1.

\section{Administration of febantel}

Febantel 25\% (Meiji Seika Kaisha, Ltd.) was used in this study. The feeds were basically moist pellets (MPs) made from shrimp of Neomysis sp., the Japanese sand lance Ammodytes personatus, horse mackerel Trachurus japonicus and assorted other feed mixtures. The drug was mixed with these MPs. The control feeds were MPs without drugs. These feeds were stored at $-20^{\circ} \mathrm{C}$ until administration.

\section{Observation of field parameters and fish condition}

During the experimental period, we measured water temperature, DO, number of dead fish and amount of feed, and observed five stages defining the appetite of fish. As to eating conditions, stage 1 was defined as excellent (eaten within $5 \mathrm{~min}$ ), stage 2 as good (eaten within 5-10 $\mathrm{min}$ ), stage 3 as appetite leading to consumption of $70 \%-100 \%$ of the amount of feed provided, stage 4 as appetite leading to consumption of less than $70 \%$ of the amount of feed provided and stage 5 as virtually no feeding.

\section{Efficacy of febantel}

The numbers of mature and immature $H$. okamotoi worms were counted using the method described by Anshary et al. (2001), with some modifications (Kimura et al., 2006). The statistical significance level of the data was judged using Mann-Whitney's U-test $(p<0.05)$ by comparing the number of $H$. okamotoi detected between the same dosage groups before and after administration. Worms were counted 5 days before and 3 days after administration. The efficacy of febantel was demonstrated according to the eradication rate of worms by the following formula.

$$
\% \text { efficacy }=[1-(\mathrm{Pa} / \mathrm{Pb})] \times 100
$$

where $\mathrm{Pa}$ is the average number of worms detected after drug administration and $\mathrm{Pb}$ is the number of worms detected before administration in the same dosage group.

\section{Results}

Water temperature during the experimental period fluctuated between $14.9^{\circ} \mathrm{C}$ and $26.8^{\circ} \mathrm{C}$, the DO concentration between $5.8 \mathrm{mg} / \mathrm{L}$ and $8.6 \mathrm{mg} / \mathrm{L}$. No abnormalities were recognized in these fluctuations. The observations of appetite and daily mortality rate in the experimental groups are presented in Table 2.

In Test $\mathrm{C}-1$, the control group had a daily mortality rate exceeding $0.1 \%$, while both administration groups had rates below $0.1 \%$. Moreover, the appetites of both administration groups also increased three days after starting administration. Therefore, the main cause of fish death in the control group was suggested to be $H$. okamotoi infection, since the number of worms after 
Table 2. Appetite and number of dead fish in field trials of febantel

\begin{tabular}{|c|c|c|c|c|c|c|c|c|c|c|c|c|c|c|c|c|}
\hline \multirow{2}{*}{\multicolumn{2}{|c|}{$\begin{array}{l}\text { Examination } \\
\text { group }\end{array}$}} & \multirow{2}{*}{ Conditions } & \multicolumn{13}{|c|}{ Experimental period in days } & \multirow{2}{*}{$\begin{array}{c}\% \text { cumulative mortality } \\
(\% \text { daily mortality })^{*}\end{array}$} \\
\hline & & & 1 & 2 & 3 & 4 & 5 & 6 & 7 & 8 & 9 & 10 & 11 & 12 & 13 & \\
\hline \multirow{6}{*}{$A-1$} & \multirow{2}{*}{ Control } & $A^{*}$ & \multirow[t]{2}{*}{1} & \multirow[t]{2}{*}{1} & \multirow[t]{2}{*}{1} & 1 & \multirow[t]{2}{*}{1} & 1 & \multirow[t]{2}{*}{1} & 1 & 1 & 1 & 1 & 1 & 1 & \\
\hline & & $\mathrm{B}^{*}$ & & & & 3 & & 1 & & 3 & 6 & 7 & 7 & 6 & 7 & $40(0.091)$ \\
\hline & \multirow{2}{*}{$12.5 \mathrm{mg} / \mathrm{kg}$} & A & \multirow[t]{2}{*}{1} & \multirow[t]{2}{*}{1} & \multirow[t]{2}{*}{1} & 1 & \multirow[t]{2}{*}{1} & 1 & \multirow[t]{2}{*}{1} & 1 & 1 & 1 & 1 & 1 & 1 & \\
\hline & & $B$ & & & & 4 & & 1 & & 2 & 3 & 4 & 7 & 4 & 7 & $32(0.074)$ \\
\hline & \multirow{2}{*}{$25 \mathrm{mg} / \mathrm{kg}$} & A & \multirow[t]{2}{*}{1} & \multirow[t]{2}{*}{1} & \multirow[t]{2}{*}{1} & 1 & \multirow[t]{2}{*}{1} & 1 & 1 & 1 & 1 & 1 & 1 & 1 & 1 & \\
\hline & & $\mathrm{B}$ & & & & 5 & & 1 & & 2 & 2 & 4 & 6 & 4 & 6 & $30(0.070)$ \\
\hline & Control & A & 2 & 2 & 2 & 2 & - & 2 & 2 & 2 & 2 & 2 & 2 & 2 & 2 & \\
\hline & control & B & 3 & 1 & 5 & & & 1 & 2 & 1 & 2 & 4 & 15 & & 2 & $33(0.094)$ \\
\hline & & A & 2 & 2 & 2 & 2 & - & 2 & 2 & 2 & 1 & 1 & 1 & 1 & 1 & \\
\hline & & $\mathrm{B}$ & 3 & 2 & 5 & & & 1 & & & 2 & 3 & 10 & & & $23(0.066)$ \\
\hline & & A & 2 & 2 & 2 & 2 & - & 2 & 2 & 2 & 2 & 2 & 2 & 2 & 2 & \\
\hline & $25 \mathrm{mg} / \mathrm{kg}$ & $\mathrm{B}$ & 2 & 2 & 3 & & & & & & 1 & 2 & 7 & & & $15(0.043)$ \\
\hline & & A & 1 & 1 & 1 & 1 & 1 & 1 & 1 & 1 & 1 & 2 & 2 & 2 & 2 & \\
\hline & & $\mathrm{B}$ & & & & & & 4 & 4 & 8 & 5 & 1 & 7 & 4 & 10 & $43(0.079)$ \\
\hline $\mathrm{B}$ & & A & 1 & 1 & 1 & 1 & 1 & 1 & 1 & 1 & 1 & 2 & 2 & 2 & 2 & \\
\hline B & $12.5 \mathrm{mg} / \mathrm{kg}$ & B & & & & & & 1 & & 1 & & 3 & 6 & 3 & 3 & $17(0.045)$ \\
\hline & $-x_{3}$ & A & 1 & 1 & 1 & 1 & 1 & 1 & 1 & 1 & 1 & 2 & 2 & 2 & 2 & \\
\hline & $25 \mathrm{mg} / \mathrm{kg}$ & $\mathrm{B}$ & & & & & & 2 & 2 & 6 & 1 & 4 & 3 & 3 & 4 & $25(0.060)$ \\
\hline & Control & A & 2 & 2 & 2 & 2 & 2 & 2 & 2 & 2 & 2 & 2 & 2 & 2 & 2 & \\
\hline & Comitiol & $B$ & & & 3 & 2 & 3 & 5 & 3 & 3 & 7 & 10 & 10 & 0 & 15 & $61(0.168)$ \\
\hline & & A & 2 & 2 & 2 & 2 & 2 & 2 & 2 & 1 & 1 & 1 & 1 & 1 & 1 & \\
\hline & $12.5 \mathrm{~m}$ & B & & & 2 & 3 & 2 & 2 & 3 & 0 & 2 & 0 & 0 & 0 & 1 & $15(0.038)$ \\
\hline & & A & 2 & 2 & 2 & 2 & 2 & 2 & 2 & 1 & 1 & 1 & 1 & 1 & 1 & \\
\hline & $2517 \mathrm{~g} / \mathrm{kg}$ & $\mathrm{B}$ & & & 2 & 3 & 3 & 1 & 3 & 3 & 3 & 2 & 3 & 0 & 6 & $29(0.074)$ \\
\hline & & A & 1 & 1 & 1 & 1 & - & 1 & 1 & 1 & 1 & 1 & 1 & 1 & 1 & \\
\hline & control & B & & & & & & 1 & & 1 & 2 & 1 & 2 & & 1 & $8(0.021)$ \\
\hline$C-2$ & $125 \mathrm{ma} / \mathrm{kg}$ & A & 1 & 1 & 1 & 1 & - & 1 & 2 & 2 & 2 & 2 & 2 & 2 & 2 & \\
\hline & $12.5 \mathrm{mg} / \mathrm{kg}$ & B & & & & & & 1 & 2 & 1 & 1 & 2 & 1 & & 1 & $9(0.024)$ \\
\hline & & A & 2 & 2 & 2 & 2 & - & 2 & 2 & 2 & 2 & 2 & 2 & 2 & 2 & \\
\hline & $20 \mathrm{mg} / \mathrm{kg}$ & $\mathrm{B}$ & & & & & & 4 & 2 & 1 & 2 & 1 & 3 & & 2 & $15(0.047)$ \\
\hline & Control & A & 1 & 1 & 1 & 1 & - & 1 & 2 & 2 & 2 & 2 & - & 1 & 1 & \\
\hline & contiror & B & & & & & & & & & & & & 1 & & $1(0.002)$ \\
\hline م & & A & 1 & 1 & 1 & 1 & - & 1 & 1 & 1 & 1 & 1 & - & 1 & 1 & \\
\hline U & T2.5 ming/kg & $B$ & & & & & & & & & & 1 & & & & $1(0.002)$ \\
\hline & $25 \mathrm{ma} / \mathrm{kg}$ & A & 1 & 1 & 1 & 1 & - & 1 & 1 & 1 & 1 & 1 & - & 1 & 1 & \\
\hline & & B & & & & & & & & & & & & & & $0(0.000)$ \\
\hline
\end{tabular}

*A : Appetite of fish, *B : Number of dead fish.

Appetite of fish is indicated as follows.

1: Excellent activity (all feed eaten with in $5 \mathrm{~min}$.).

2: Good activity (all feed eaten with in 5-10 min.).

3: No or reduced eating activity.

Gray area shows drug administration period. - - without observation.

*: Daily mortality (total of dead fish/initial number of fish/experimental period in days) $\times 100(\%)$.

administration was the highest in this group (Table 3).

In other experiment groups, appetite was categorized as 1 or 2 , and decreased slightly with decreasing water temperature. Fish ate all feed containing the drug and no detrimental influence on appetite was observed. Furthermore, the daily mortality rate was lower than $0.1 \%$. We observed no abnormal deaths of fish.

Numbers of mature and immature worms before administration were compared with those after administration (Fig. 1). Numbers of mature worms in all control groups increased after administration and those of immature worms in four groups increased. Mature worms in control groups for B and C-2 and immature worms in control groups for $\mathrm{C}-1$ and $\mathrm{D}$ increased over $100 \%$. The eradication rates of mature and immature worms of high dose groups were higher than those of low dose groups. 
Table 3. Efficacy of febantel against Heterobothrium okamotoi in the field trials

\begin{tabular}{|c|c|c|c|c|c|c|c|}
\hline \multirow{2}{*}{\multicolumn{2}{|c|}{ Experimental group }} & \multicolumn{3}{|c|}{ number of mature worms } & \multicolumn{3}{|c|}{ number of immature worms } \\
\hline & & \multirow{2}{*}{$\begin{array}{c}\text { before } \\
\text { administration } \\
\text { (S.D.) }\end{array}$} & \multirow{2}{*}{$\begin{array}{c}\begin{array}{c}\text { after } \\
\text { administration } \\
\text { (S.D.) }\end{array} \\
5.3(3.1)\end{array}$} & \multirow[t]{2}{*}{$\begin{array}{c}\text { Eradication rate } \\
(\%)\end{array}$} & \multirow{2}{*}{$\begin{array}{c}\begin{array}{c}\text { before } \\
\text { administration } \\
\text { (S.D.) }\end{array} \\
23.0(7.2)\end{array}$} & \multirow{2}{*}{$\begin{array}{c}\begin{array}{c}\text { after } \\
\text { administration } \\
\text { (S.D.) }\end{array} \\
22.3(8.2)\end{array}$} & \multirow[t]{2}{*}{$\begin{array}{c}\text { Eradication rate } \\
(\%)\end{array}$} \\
\hline & Control & & & & & & \\
\hline \multirow[t]{3}{*}{$A-1$} & $12.5 \mathrm{mg} / \mathrm{kg}$ & $4.4(2.4)$ & $4.2(2.3)$ & 4.5 & $23.8(8.4)$ & $20.7(8.0)$ & 13.2 \\
\hline & $25 \mathrm{mg} / \mathrm{kg}$ & $5.2(3.1)$ & $1.9(1.9)^{*}$ & 63.5 & $26.4(11.3)$ & $21.8(10.8)^{*}$ & 17.4 \\
\hline & Control & $9.5(8.5)$ & $11.8(7.7)$ & & $28.1(11.8)$ & $22.0(12.6)$ & \\
\hline \multirow[t]{3}{*}{ A-2 } & $12.5 \mathrm{mg} / \mathrm{kg}$ & $7.3(5.5)$ & $5.1(6.3)$ & 22.7 & $32.8(11.2)$ & $16.2(13.9)^{*}$ & 50.6 \\
\hline & $25 \mathrm{mg} / \mathrm{kg}$ & $9.2(4.1)$ & $3.6(3.3) *$ & 56.6 & $45.1(13.0)$ & $8.6(8.3)^{*}$ & 80.9 \\
\hline & Control & $4.5(2.2)$ & $10.3(9.6)$ & & $13.3(6.1)$ & $25.2(14.0)$ & \\
\hline \multirow[t]{3}{*}{ B } & $12.5 \mathrm{mg} / \mathrm{kg}$ & $4.6(2.2)$ & $5.3(3.2)$ & -15.2 & $19.4(8.8)$ & $21.9(9.5)$ & -12.9 \\
\hline & $25 \mathrm{mg} / \mathrm{kg}$ & $3.8(2.0)$ & $1.8(1.5) *$ & 52.6 & $20.6(9.2)$ & $15.6(8.0)$ & 24.3 \\
\hline & Control & $8.7(2.7)$ & $14.2(5.5)$ & & $21.5(6.5)$ & $45.9(21.5)$ & \\
\hline \multirow[t]{3}{*}{$\mathrm{C}-1$} & $12.5 \mathrm{mg} / \mathrm{kg}$ & $7.7(4.5)$ & $10.6(4.5)$ & -37.7 & $22.6(12.8)$ & $15.4(10.1)^{*}$ & 31.9 \\
\hline & $25 \mathrm{mg} / \mathrm{kg}$ & $9.7(5.5)$ & $6.7(3.3)$ & 30.9 & $27.7(22.2)$ & $12.9(8.5)^{*}$ & 53.4 \\
\hline & Control & $3.6(4.3)$ & $7.2(6.1)$ & & $24.2(12.3)$ & $35.6(38.7)$ & \\
\hline \multirow[t]{3}{*}{ C-2 } & $12.5 \mathrm{mg} / \mathrm{kg}$ & $9.8(6.6)$ & $7.1(5.6)$ & 27.6 & 45.5 (19.3) & $25.8(22.9)^{*}$ & 43.3 \\
\hline & $25 \mathrm{mg} / \mathrm{kg}$ & $15.8(8.0)$ & $3.6(4.2) *$ & 77.2 & $51.0(21.3)$ & $32.2(36.1)^{*}$ & 36.7 \\
\hline & Control & $4.4(4.7)$ & $4.4(4.3)$ & & $7.3(4.9)$ & $20.3(13.9)$ & \\
\hline \multirow[t]{2}{*}{$\mathrm{D}$} & $12.5 \mathrm{mg} / \mathrm{kg}$ & $2.6(3.7)$ & $2.2(2.8)$ & 18.5 & $10.3(7.3)$ & $3.2(4.1)^{*}$ & 68.9 \\
\hline & 25 mg/kg & $3.7(5.8)$ & $0.9(1.5)^{*}$ & 75.7 & $17.5(15.2)$ & $6.8(23.2)^{*}$ & 60.6 \\
\hline
\end{tabular}

*: Significantly lower $(p<0.05)$ than that before administration.

The efficacies of febantel against $H$. okamotoi are shown in Table 3. In the efficacy studies of high dose administration against mature worms, five out of six experimental groups showed eradication rates of over $50 \%$, significantly lower number of worms than those of before administration. On the other hand, no low dose groups showed significantly lower eradication rates against mature worms. In the efficacy studies of high dose administration against immature worms, five out of six experiment groups showed significantly lower number of worms than those of before administration. Low dose groups showed significantly lower eradication rates against mature worms in four out of six examination groups.

\section{Discussion}

In this field trial, we observed no adverse effect of febantel on fish appetite or mortality rates. The present results were in good accordance with those in the previous experiment, in which $50 \mathrm{mg} / \mathrm{kg}$ of febantel was administered to tiger puffers in land base tanks (Kinmura et al., 2007). Furthermore, the blood concentration of fenbendazole, metabolized from febantel, was essentially zero 3 days after the end of administration (Kimura et al., 2007). Therefore, febantel was thought to be safe for use in the field.

The efficacy of febantel against mature of $H$. okamotoi was demonstrated in this field trial, confirming the results obtained using tiger puffers raised in land based tanks (Kimura et al., 2006). Low dose administration in this trial was less effective than high dose administration. However, worm eradication rates were lower than those obtained in a previous experiment using land based tanks and the individual difference in the number of parasites was larger than in our previous study (Kimura et al., 2006).

One possible explanation for this lower effect is that tiger puffers at culture sites are constantly infected by oncomiracidia, the infective stage of monogeneans. The water temperature in this field trial changed from $24^{\circ} \mathrm{C}$ in October to $17^{\circ} \mathrm{C}$ in December. This temperature range is preferrable for the proliferation of $H$. okamotoi (Ogawa and Inouye, 1997a ), and we observed numerous eggs entangled on the net cage which was adjacent to the experiment site.

We found not only administration of febantel but also changes of the net cage before or after administration to possibly control this gill fluke disease by decreasing the chance of re-infection with $\mathrm{H}$. okamotoi more effectively. Furthermore, this disease might be effectively controlled by administering febantel to all fish within the entire area of a culture site.

Since tiger puffers do not have a developed stomach, the feed is gradually digested over a long period of time by a thicker and shorter intestine than that of red sea bream Pagrus major which has a developed stomach (Takii et al., 1997). Therefore, tiger puffer easily vomit undigested portions of excessive feed. Moreover, puffers often vomit excessive feed, when they 

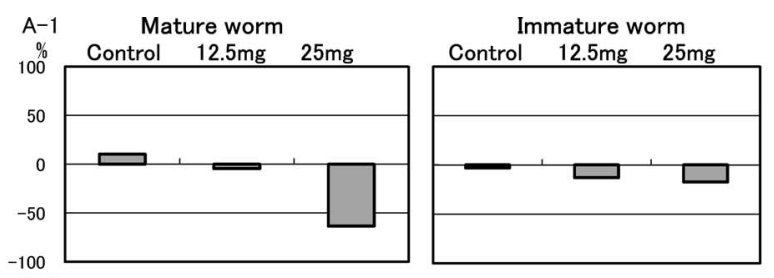

A-2
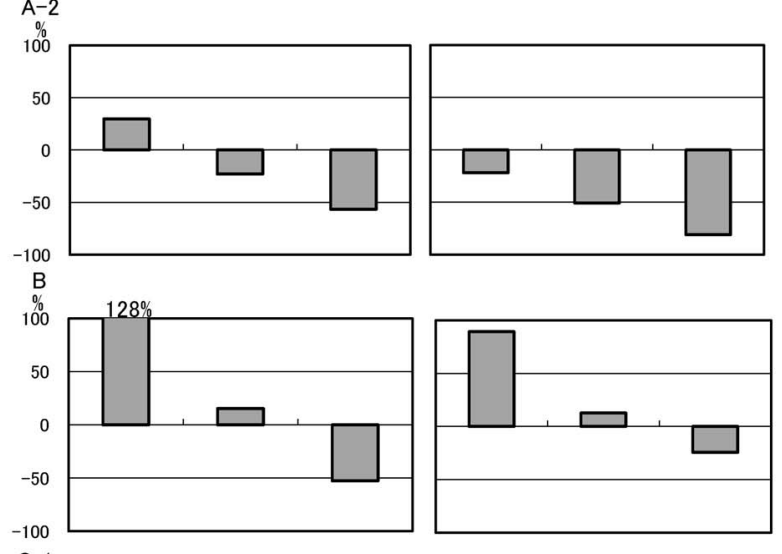

C-1
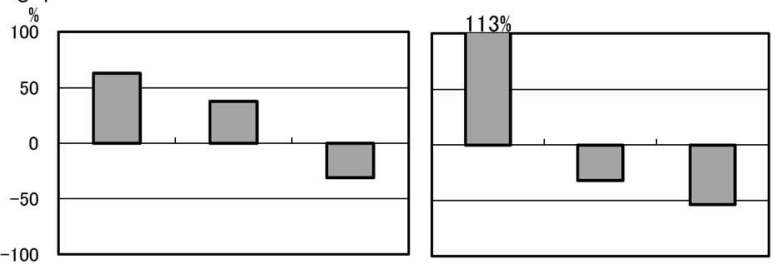

C-2
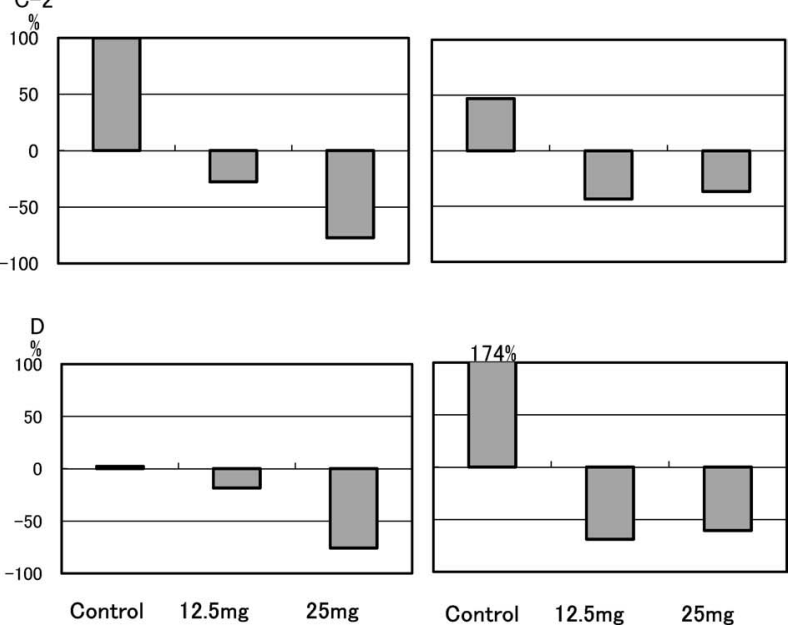

Fig. 1. Changes in the numbers of mature (left column) and immature (right column) worms of Heterobothrium okamotoi before and after administration of febantel. Results are the percentage increase or decrease in worms after drug administration as compared with those before administration. bite each other under stressed conditions. If feed containing the drug is not digested adequately, the drug is unlikely to be absorbed and some portion of the drug will be lost via vomiting. Effects of febantel at the feeding rate of at least $3 \%$ of fish body weight in the $A-1, A-2, B$ and $C-1$ groups were lower than those at the feeding rate of less than $3 \%$ in $\mathrm{C}-2$ and $\mathrm{D}$. It was thought to be important to administer feed containing the drug at a feeding rate lower than $3 \%$. When tiger puffers are fed several times a day, it is recommended to give them fish feed containing the drug to fish at the last feeding occasion for the drug.

\section{References}

Anshary, H., K. Ogawa, M. Higuchi and T. Fujii (2001): A study of long-term change in summer infection levels of Japanese flounder Paralicthys olivaceus with the monogenean Neoheterobothrium hirame in the central Sea of Japan, with an application of a new technique for collecting small parasites from the gill filaments. Fish Pathol., 36, 27-32.

Kimura, T., M. Sameshima, Y. Nomura, J. Morita, H. Mizoguchi and M. Ishihara (2006): Efficacy of orally administered febantel against monogenean Heterobothrium okamotoi infection of cultured tiger puffer Takifugu rubripes. Fish Pathol., 41, 147-151.

Kimura, T., J. Morita, Y. Nomura, J. Enomoto, H. Mizoguchi and M. Ishihara (2007): Concentration-time profile of febantel in cultured tiger puffer Takifugu rubripes. Aquacult. Sci., 55, 279-284. (in Japanese)

Ogawa, K. and K. Inouye (1997a) : Heterobothrium infection of cultured tiger puffer, Takifugu rubripes-A field observation. Fish Pathol., 32, 15-20.

Ogawa, K. and K. Inouye (1997b) : Parasites of cultured tiger puffer (Takifugu rubripes) and their seasonal occurrences, with descriptions of two new species of Gyrodactylus. Fish Pathol., 40, 169-174.

Ogawa, K. (2002): Impacts of diclidophorid monogenean infections on fisheries in Japan. Int. J. Parasitol., 32, 373-380.

Okamoto, R. (1963): On the problems of a monogenetic trematode infection of puffers from the Inland Sea of Japan. Suisanzoshoku, Special Issue, 3, 17-29. (in Japanese)

Takii, K., K. Konishi, M. Ukawa, M. Nakamura and H. Kumai (1997): Comparison of digestive and absorptive functions between tiger puffer and red sea bream. Fish. Sci., 63, 349-354. 